\title{
The Relationship of Skilled Labour Shortages and Project Performance in Construction Industry: A Conceptual Framework
}

\author{
Nurul Safwah Mohd Yusoff ${ }^{1}$, Faizul Azli Mohd Rahim ${ }^{1 *}$, Loo Siaw Chuing ${ }^{1}$ \\ ${ }^{1}$ Centre for Building, Construction \& Tropical Architecture (BuCTA), Faculty of Built Environment, \\ Universiti Malaya, 50603 Kuala Lumpur, Malaysia \\ *azli@um.edu.my
}

The construction industry is recognised as one of the major economic sectors that significantly contribute to socio-economic development. However, the skilled labour shortage is one factor that affects the success of projects in the construction industry. Therefore, this paper aims to study the effects of skilled labour shortages on construction project performance. A questionnaire survey was conducted with 42 construction practitioners. The hypotheses were tested by using a Partial Least Square (PLS) method. The results indicate that project-related factors and human capital factors affecting skilled labour shortages in construction projects and skilled labour shortages have affected construction projects' performance. This finding's implication is useful for construction industry players by better understanding successfully managing construction projects.

Keywords: Construction, human capital factors, project-related factors, project performance, skilled labour shortages. 


\subsection{INTRODUCTION}

The project performance decides the success of a construction project. Generally, a construction project is deemed successful when the three criteria in measuring the project performance were achieved, to be precise, the completion on schedule, within budget and meets quality requirements (Cepeda et al., 2018; Fernando et al., 2016; Kabirifar \& Mojtahedi, 2019; PapkeShields et al., 2010; Sunindijo and Zou, 2012; Yong \& Mustaffa, 2017). However, the involvement of an extended period, complicated processes, financially intensive and complex organisation structures (Bilau et al., 2015; Farooqui \& Saqib, 2010; Jarkas and Younes, 2014; Perera et al., 2014; Oseghale et al., 2015), as these characteristics made the uniqueness of the construction project would become the problems that affect their performances.

As an industry that relies heavily on human capital (Chin, 2012), the construction industry requires various skills and professional levels, such as architects, engineers, consultants, regulators, and others, to ensure their success. The construction industry acts as a backbone of the economic growth of any country; therefore, it influences other industry's role on all levels in an economy (Alaloul et al., 2021). These linkages with other industries are dependent on performance; therefore, a change in the construction industry has a considerable influence on the socio-economic aspects of any nation (Khan et al., 2014).

Skill is defined as an ability to perform a task at a certain level of competence (Shah and Burke, 2003). Pheng and Chuan (2006) stated that human factors played an important role in determining a project's performance. The ability to meet the requirements of cost, time, and quality of the construction work depends significantly on skilled workers' performance (Praveen et al., 2011). Therefore, skilled labour is recognised as the key resource that directly impacts the performance of a construction project (Baloyi \& Bekker, 2011; Zaki et al., 2012; Othman, 2014). However, skilled labour shortages often reported as a significant challenge in the industry that works with people skills (Healy et al., 2011; Kwai, 2011; Mavromas et al., 2013; Shafie et al., 2014; Yaman et al., 2015).

As Shah and Burke (2003) defined, a skilled shortage is when the demand of labours for a specific job is more than the supply of qualified, available, and willing to work labours under existing market conditions. Skilled worker shortages have always been interpreted as "hard-to-fill vacancies" or "skill gaps" (Jones \& Goss, 1991; Haskel \& Martin, 1993; Bosworth, 1993; Veneri, 1999). The greatest challenge in the construction industry globally is the shortage of skilled labour, in which the industry itself requires a higher level of skills (Healy et al., 2011; Olsen, 2012; Mavromas et al., 2013).

Previous research has shown that the shortage of skilled labours in construction projects occurred because of two main factors: humanrelated factors and factors related to the project itself (Bilau et al., 2015; Shehu et al., 2014; Ibrahim, 2013). The role of human-related factors is vital to the success of construction projects. Crook et al. (2011) claimed that the project's high performance is dependent on the human capital in the business practices. Jaafar and Khalatbari (2013), Yong and Mustaffa (2017) and Fernando et al. (2016) have noted a significant relationship between project 
managers' management knowledge and technical skills with the construction projects' performance.

The importance of the human-capital factors in the success of construction projects has been applied as the underpinning theory in the previous research. Previous research has shown that skilled labour shortages impact the construction project's performance directly or indirectly (Baloyi \& Bekker, 2011; Jaafar \& Khalatbari, 2013; The Star Online, 2011; Zaki et al., 2012). Thus, it was proven that the investment in human capital could produce skilled individuals who have significantly impact organisational performance (Becker, 1964; Crook et al., 2011; Mahsud et al., 2011; Razak et al., 2015; Ho, 2016).

The uncertain working environment and complexity are the project-related factors that lead people hesitant to work in construction projects (Salleh et al., 2014; Oseghale et al., 2015). Moreover, the construction sector images are poor and unattractive to the public. According to Zaki et al. (2012), some of the driving factors for this occurrence include poor career path and hideous job, low wages, poor working environment, contractor's acquisitiveness, and economic factors (Baqadir, 2013; Olsen et al., 2012). Low image mainly comes from construction nature, which they think is dirty, dangerous, and difficult (3D's) environment (Bilau et al., 2015; Lobo \& Wilkinson, 2008; Oseghale et al., 2015).

As skilled labour is one of the fundamental resources in ensuring the success of construction projects, the shortage of labours directly affects project performance (Hajela, 2012; Ibrahim, 2013; Jarkas \& Younes, 2014; Karimi et al., 2016). The previous research showed that labour shortages would reflect the poor performance of construction projects (Baloyi and Bekker, 2011; Hamid et al., 2013; Othman, 2014). The surging of project cost and project delay is among the consequences of skilled labour shortages (Hwang et al., 2015; Jarkas and Haupt, 2015; Karimi et al., 2017). In addition, Karimi et al. (2016) have demonstrated a strong relationship between the increased skilled labour staffing difficulty and increased total recordable incident rate. The impact of construction injuries on project cost performance concerning the indirect cost of damages is substantial.

This study aims to propose a conceptual framework on the relationships between skilled labour shortages and project performance. This study focused on skilled labour shortages, specifically the human capital and projectrelated factors, on the construction project's performance.

\subsection{LITERATURE REVIEW}

There is numerous research earlier have studied the effects of skilled labour shortages on construction project performance. The human capital and project-related factors and their relationships affecting the performance of the construction project were the main factors been studied.

\subsection{Human Capital related factors}

The construction industry relies heavily on human capital (Chin, 2012), specifically skilled labour, which has been recognised as the key resource that directly impacts a construction project's performance. However, skilled labour shortages are often reported as a significant challenge worldwide in the construction industry (Hamid et al., 2013; Healy et al., 2015). 
Skilled labour is a valuable and fundamental resource that enables the organisation to achieve better performance. Generally, the availability of skilled labour shall represent the human capital factors in an organisation.

Human capital incorporates genetic inheritance, attitude, education, and people experience in their life and business (Hashim et al., 2015; Parvaiz, 2014; Amrizah \& Nawal, 2013). Human capital is conceptualised in two ways (Kwon, 2009; Parvaiz, 2014). The first concept utilises human capital as 'labour force' where additional value can be added to the economy by using the input of 'labour force' as other production factors such as financial capital, land, machinery, and labour hours (Kwon, 2009). Meanwhile, the second concept assumes human capital as an investment made by the public to enhance their productivity, such as knowledge, skills, competency, and experiences (Coff, 2002; Kwon, 2009; Parvaiz, 2014). Among those concepts of human capital, it tends to be recognised that the latter is more important than the first (Beach, 2009).

Human capital refers to experts or employee's skills, knowledge and experience shared with their organisation to add value (Baron, 2011). Much of the empirical literature has shown that investment in human capital (especially knowledge and skills through education and training) significantly impacts various social components and overall economic growth (Muathe, 2018; Parvaiz, 2014; Pelinescu, 2015). Marimuthu et al. (2009) suggested that training, education, and other professional initiatives help employees develop knowledge, skills, abilities, values, and social assets, which indirectly contribute to the overall organisational performance.
According to Crook et al. (2011), human capital has a long history in strategic management seen as a source of value, both at the managerial and individual levels. Researchers have long understood that superior human capital might lead to sustainable performance advantages for organisations (Becker, 1983; Mincer, 1974). It improves the assets and employees, leading to increased productivity and maintaining a competitive advantage (Amrizah \& Nawal, 2013; Muathe, 2018). It has regarded as the most valuable asset in any business is human resources compared to other capitals or equipment. However, it was also believed to be the most ignored asset by the firms. Therefore, a human can be considered a valuable asset or liability to an organisation if not properly managed (Khan et al., 2010).

Borjas (2005) advises that raising labour wages and introducing benefits would increase the labour supply. However, the compensation for employees and managers is related to the education and experience they have (Mavromaras et al., 2009; Weber, 2014). For instance, Hamid et al. (2013) report that one of the factors contributing to the construction labour shortage in Malaysia is the changes in the national education framework which produced highly skilled young people. With their skills, these people are more likely to migrate to highwage countries or expand their careers in the manufacturing sector, which offers better employment conditions.

Watson (2007) identifies several influential factors concerning skill shortages in the Australian construction industry. The author highlighted that the funding contributions made to training and skill development, low-level investment to education and training, less 
investment in the apprenticeship system, imbalanced level of labour supply and demand, an ageing workforce, and industrial relations, immigration and migration are among factors that have a significant effect on skilled labour availability in the industry.

Therefore, human capital factors, including employee's education, skills, wages, and training, are selected as the determinant factors for skilled labour shortages in this study. Hence, the proposed research hypothesis is:

$\mathrm{H}_{1}$ : Human capital factors are positively related to skilled labour shortages.

\subsection{Project-related factors}

The project-related factors are considered in this framework as an accompaniment to the human capital factors. Prior research stated that the most apparent reason for the shortage of labour in the construction industry is due to the inability to attract and retain talent when there is an increasing demand within the workforce (Ho, 2016; Oseghale et al., 2015; Ismail \& Yuliyusman, 2014; Watson, 2007; Lill, 2009). In this study, project-related factors, including the working conditions, project complexity and foreign labours, are selected as the determinant factors for skilled labour shortages.

For instance, poor working conditions, such as the health, safety, and welfare facilities in the construction industry, have influenced human resources. The perception of the "dirty, difficult and dangerous (3D)" has always been associated with this industry and has been indirectly discouraging many existing and new talents to "stand back" from the industry, ultimately leads to the shortage of skilled labours (Hamid et al., 2013, Theng et al., 2020). The unwillingness and reluctance of local workers to undertake 3D jobs create vacancies filled by migrant workers (Wahab, 2020).

Salleh et al. (2014) identify several factors influencing the local labour shortage. The phenomenon is very much dependent on the perception towards construction jobs, working environment, site accommodations and services, wages or remuneration package, and the job outlook. Furthermore, Ho (2016) and Karimi et al. (2016) stated that the hazardous working environment also becomes one factor that induced the shortage of skilled labour in the construction project. They reported that the fatal accident that happened is inculpated to a significant drop in new recruitment in the industry. The impact of construction injuries on project cost performance concerning the indirect cost of damages is substantial.

Despite having the poor working condition and site safety as the main contribution to the phenomenon, Healy et al. (2015) discovered that the skilled labour shortage had been influenced by causes such as specialisation of knowledge, uncertain demand for specific products or service in the long run, and geographic location of the projects. Boswell et al. (2004) claimed that other than the remuneration packages, the security of the worker's employment status and career advancement is the considerations essential to attract or retain labour in the industry. However, most construction labourers are currently employed daily and have no long-term job security (Oseghale et al., 2015; Hamid et al., 2013; Lill, 2008).

One of the immediate solutions in managing labour shortages is to hire foreign labours. Salleh et al. (2014) have stated that the shortage of labour in the Malaysian construction industry 
has led to the inflow of foreign labours, primarily from Indonesia and Bangladesh, to fill the vacancies or reduce labour shortages the fastest and cheapest way. The above statement is in line with the ILO \& Australia Aid (2019) report that stated the foreign labours constitute up to $30 \%$ of the labour force (including undocumented foreign labours) in Malaysia. As of mid-2019, the estimated number of active foreign labours in the Malaysian construction industry is about 435000 people, constituting up to $21.7 \%$ of total documented foreign labours (MOHR, 2019). The over-dependence on foreign labour has indirectly affected human resource sustainability in the Malaysian construction industry (Rahim et al., 2016). The influx of unskilled foreign labours in the construction industry has worsened the skilled labours shortage (Marhani et al., 2012; Hamid et al., 2013).

Therefore, project-related factors, including the working conditions, project complexity and foreign labours, are selected as the determinant factors for skilled labour shortages in this study. Hence, the proposed research hypothesis is:

$\mathrm{H}_{2}$ : Project-related factors are positively related to skilled labour shortages.

\subsection{Skilled labour shortages and project performance}

Prior research on the skilled labour shortages (human capital factors and project-related factors) had gained interest in studying the project performance. The shortage of labour directly affects project performance in terms of cost, time, and quality since construction is a labour-intensive industry (Hajela, 2012; Ibrahim, 2013; Jarkas \& Younes, 2014). Jarkas and Younes (2014) stated that labour costs comprise $30 \%$ to $50 \%$ of the overall project costs. Hence, labour has been regarded as a fundamental resource whose efficiency determines its success.

According to Baloyi and Bekker (2011), the difficulties faced due to a shortage of skilled labours eventually lead to cost and time increases and lack of quality performance. Labour shortage is one of the risks in construction projects that can turn over projects' success with the high cost and schedule overruns (Othman, 2014). According to REHDA (Real Estate Housing Developer's Association) Malaysia, the skilled labour shortage is one factor contributing to the increasing property price (The Star Online, 2011).

Besides, Crook et al. (2011) have conducted meta-analysed effects drawn from 66 studies of the human capital-firm performance relationship and found that human capital factors are closely related to its performance. The authors also suggest that the skilled worker's investment is essential to enhance and retain its specific human capital. The shortfall of skilled labours needs to be addressed as it may affect the productivity of the industry. The research on human capital and a firm's performance conducted by Awan and Sarfraz (2013) also discovered that human capital investment significantly affects a firm's performance. Employees' satisfaction mediates the processes in between.

Construction skilled labour shortages have the potential to undermine broader economic growth. As construction firms struggle to fill in the key positions, they will be forced to propose slower schedules for vital projects, further weakening the pace of economic development. 
Brown et al. (2007) discovered that human capital factors, namely education and training, have influenced construction projects' time delivery in the UK and Saudi Arabia. Besides, labourers' availability is the influential factors impacting the schedule performance of green building projects in Singapore (Hwang et al., 2015).

Similarly, the shortage of skilled labour is among the significant construction risks considered by general contractors operating in Qatar (Jarkas and Haupt, 2015), contributing to a construction delay. Therefore, from the above discussion, the following hypothesis is proposed:

$\mathrm{H}_{3}$ : Skilled labour shortage is significantly affecting project performance.

\section{$2.4 \quad$ Hypothetical Model}

Figure 1 illustrates the proposed framework for internal resources (human capital) relationships and project characteristics in skilled labour shortages in construction projects. The relationships between the human capital and project-related factors are essential to identify the importance of skilled labours management in a project and ultimately lead to the construction project's success. This framework is conceptualised based on others' previous research (Faraji \& Abdolvand, 2016; Razak et al., 2015; Aziz \& Salleh, 2014; Meng et al., 2012; Crook et al., 2011; Watson, 2007; Fiori, 2003).

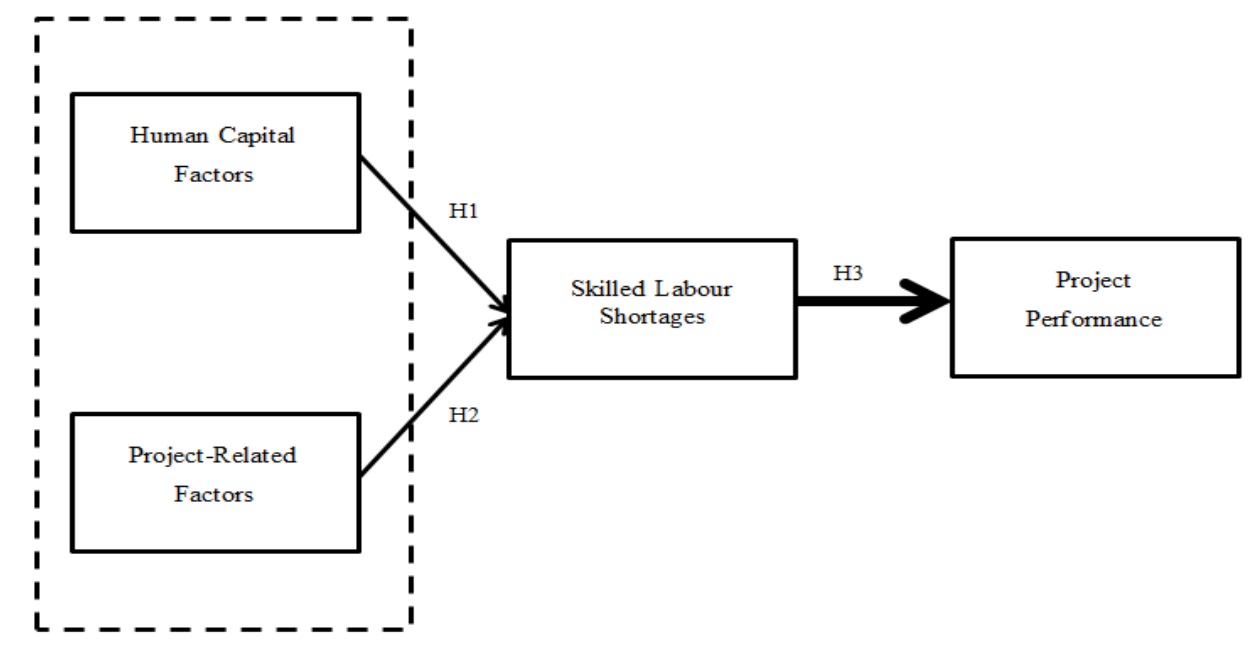

Fig. 1 - The proposed framework on the relationships of human capital factors, project-related factors and skilled labour shortages on construction project performance. 
This preliminary study was conducted as part of a PhD study to determine the effects of skilled labour shortages on construction project performance. For this preliminary study, a field survey using questionnaires were conducted, which involved a small group of construction practitioners, namely project managers, project developers and contractors, who at least once have experienced a shortage of skilled labour in their projects. The quantitative survey method describes the variables' characteristics in determining the relationship of human capital factors, project-related factors and skilled labour shortages on construction project performance. The questionnaires were developed after a thorough review of literature related to skilled labour shortages and project performance.

The targeted population is comprised of Group Seven (G7) construction organisations registered with the Construction Industry Development Board (CIDB) Malaysia as of April 2017. The selected target respondents are the construction industry's practitioners who have experienced skills shortages during their works. The reasoning is that they can clearly state the nature of these issue in their projects. Therefore, 60 questionnaires were distributed to randomly selected construction organisations in the Klang Valley based on the convenience sampling method. Although this approach has potential for bias, after considering that this is a preliminary study, the non-probability convenience sampling was considered appropriate (Hashim et al., 2015; Zakari et al., 2014).

Out of the 60 questionnaires sent, 42 firms responded, giving a response rate of $70 \%$. Considering that this is a preliminary study, the response rate gathered from the project managers, contractors and developers were considered satisfactory. According to Sekaran and Bougie (2010), sample size larger than 30 and less than 500 are appropriate for most research. Table 1 summarises the profile of respondents and their organisations.

Table 1: Respondents' demographic profile

\begin{tabular}{|l|l|c|c|}
\hline \multicolumn{2}{|c|}{ Respondent's profile } & $\begin{array}{c}\text { No. of } \\
\text { respondents }\end{array}$ & $\begin{array}{c}\text { Cumulative } \\
\text { percentage }\end{array}$ \\
\hline \multirow{5}{*}{ Position } & Contractor/Sub-contractor & 19 & $45 \%$ \\
\cline { 2 - 4 } & Project Manager & 7 & $17 \%$ \\
\cline { 2 - 4 } & Construction Developer & 5 & $12 \%$ \\
\cline { 2 - 4 } & Others & 11 & $26 \%$ \\
\hline Total & & 42 & $60 \%$ \\
\hline Experiences & <5 years & 25 & $26 \%$ \\
\cline { 2 - 4 } & 6-10 years & 11 & $9 \%$ \\
\cline { 2 - 4 } & $11-15$ years & 2 & $5 \%$ \\
\cline { 2 - 4 } & $>15$ years & 12 & $33 \%$ \\
\hline \multirow{5}{*}{ Types of projects } & Residential buildings & 14 & \\
\cline { 2 - 4 } & $\begin{array}{l}\text { Non-residential buildings } \\
\text { (commercial \& industrial } \\
\text { buildings) }\end{array}$ & & $26 \%$ \\
\cline { 2 - 4 } & $\begin{array}{l}\text { Civil engineering } \\
\text { (public infrastructures; e.g. } \\
\text { bridges \& highways) }\end{array}$ & 11 & \\
\cline { 2 - 4 } & Special trades & 5 & $12 \%$ \\
\hline
\end{tabular}




\begin{tabular}{|l|l|c|c|}
\hline \multicolumn{2}{|c|}{ Respondent's profile } & \multicolumn{1}{c|}{$\begin{array}{c}\text { No. of } \\
\text { respondents }\end{array}$} & $\begin{array}{c}\text { Cumulative } \\
\text { percentage }\end{array}$ \\
\hline & $\begin{array}{l}\text { (E.g. metal works, electrical } \\
\text { works, plumbing, sewerage } \\
\text { etc.) }\end{array}$ & & \\
\hline \multirow{5}{*}{ No. of projects involved } & $<10$ projects & 31 & $74 \%$ \\
\cline { 2 - 4 } & $11-20$ projects & 8 & $19 \%$ \\
\cline { 2 - 4 } & $21-30$ projects & 3 & $7 \%$ \\
\cline { 2 - 4 } & $>30$ projects & 0 & $0 \%$ \\
\hline \multirow{5}{*}{ Project values } & $<$ RM10 million & 11 & $26 \%$ \\
\cline { 2 - 4 } & $\geq$ RM10 million & 18 & $43 \%$ \\
\cline { 2 - 4 } & $\geq$ RM 50 million & 8 & $19 \%$ \\
\cline { 2 - 4 } & $>$ RM100 million & 10 & $24 \%$ \\
\hline \multirow{5}{*}{ Size of firm } & Small & 13 & $31 \%$ \\
\cline { 2 - 4 } & Medium & 19 & $45 \%$ \\
\cline { 2 - 4 } & Large & & \\
\hline
\end{tabular}

This study's data were analysed based on Partial Least Square (PLS) method with SmartPLS 3.0 software. PLS is a soft modelling approach to SEM, which through this technique, the relationship between hidden and observed variables can be studied in parallel. PLS-SEM works efficiently with small sample sizes, and it needs no assumptions about data distributions (Henseler et al., 2009). This study contains 42 samples, a small sample size, whereas the structural model has two main constructs and three hypotheses, making the proposed model straightforward.

Moreover, in this study, the research problems consist of hypothesised relationships of constructs (see Fig. 1), measured with observable measurement indicators. Multiple regression analysis was not a suitable multivariate data analysis (MDA) technique because it cannot assess the relationships between the latent variables (Hair et al., 2015). Thus, PLS-SEM has used the MDA technique in this study because an SEM approach incorporates multiple dependent constructs, recognises error indicators, and integrates theory with empirical data.

\subsection{MODEL DEVELOPMENT AND} ASSESSMENT

The survey received 42 replies, in which most of them ( $60 \%$ or 25 persons) are with less than five years of relevant working experience. In contrast, the remaining ( $40 \%$ or 17 persons) having six to ten years of relevant working experience. The types of projects that the respondents involved are residential buildings ( $29 \%$ or 12 persons), non-residential buildings including commercial and industrial buildings (33\% or 14 persons), civil engineering or public infrastructure projects such as bridges and highways (26\% or 11 persons) and other specialised trades in which their primary businesses are related to metal, electrical, plumbing and sewerage works.

Most of the respondents, which contributed $74 \%$ or 31 of them, are involved in less than ten projects in their working experience. $19 \%$ or eight respondents contribute around eleven to twenty projects, and $7 \%$ or three respondents are marking their twenty-one to thirty projects in their working experience.

It was worth mentioning that the respondents involved in projects of different budgets, starting from less than RM10 million $(26 \%$ or 
11 respondents), more than RM10 million but less than RM50 million $(43 \%$ or 18 respondents), more than RM50 million but less than RM100 million $(19 \%$ or eight respondents), and more than RM100 million (12\% or five respondents). Most of the respondents come from a large organisation, which contributed $45 \%$ or 19 . There are $31 \%$ or 13 respondents from the medium-sized organisation, and $24 \%$ or ten respondents are from small organisations.

The Partial Least Squares approach to Structural Equation Modelling (PLS-SEM) was used to validate the model (from the proposed framework in Fig-1) because the model constitutes both reflective and formative constructs and violates the assumptions of multivariate normality (Ali et al., 2016; Tehseen et al., 2017). The measurement model's evaluation was done by performing the reliability and validity analyses on the model's measures. The structural model was analysed by estimating the paths between the model's constructs and determining the path relationship's significance.

First, the measurement model was evaluated for convergent validity, internal consistency, and discriminant validity. The purpose of assessing the convergent validity is to ensure that the indicators are assumed to measure each construct and not another construct (Hulland, 1999). It is the extent to which an indicator is consistent with what it intends to measure (Urbach \& Ahlemann, 2010; Hair et al., 2014). The convergent validity was examined through the factor loadings, indicator reliability and average variance extracted (AVE) (Hair et al., 2017; Hair et al., 2014).
According to Hair et al. (2017), the factor loadings are acceptable between 0.6-0.7 for social science studies. However, factor loadings equal to and more significant than 0.5 are still acceptable if the summation of loadings results in high loading scores, contributing to AVE scores greater than 0.5 (Byrne, 2016). Likewise, the AVE value above 0.5 suggests an adequate convergent validity (Hair et al., 2017; Bagozzi \& Yi, 1988). In this study, all the latent variables were having factor loadings and AVEs at the recommended levels.

The constructs' internal consistency was measured using the composite reliability (CR) proposed by Hoffmann and Birnbrich (2012). As Herath and Rao (2009) proposed, the threshold criterion for $\mathrm{CR}$ is 0.70 , and all the latent variables involved in this study exceeded the threshold criterion. It is important to note that values above 0.95 are not desirable because they indicate that the indicator variables measure the same phenomenon and are unlikely to be a valid measure of the construct (Hair et al., 2014). Besides, the composite reliability values less than 0.6 depict a lack of internal consistency reliability.

Subsequently, the discriminant validity of the model is also assessed. Henseler et al. (2015) suggested assessing the correlation's heterotrait-monotrait ratio (HTMT) to examine the discriminant validity. The discriminant validity is the extent to which a construct is truly distinct from other constructs by empirical standard (Hulland, 1999). Hence, establishing a valid discriminant implies that a construct is unique and absorbs phenomena not represented by other constructs measurement models (Hair et al., 2017). This approach shows the estimation of the true correlation between two 
latent variables. A threshold value of 0.90 has been suggested for HTMT (Henseler et al., 2015 ), and if the value is above 0.90 , it shows a lack of discriminant validity. Moreover, the confidence interval of the HTMT should not involve the value of 1 . Table 2 shows the assessment result of the measurement model.

Table 2: Assessment result of the measurement model

\begin{tabular}{|c|c|c|c|c|c|c|c|}
\hline \multirow[b]{2}{*}{ Construct } & \multirow[b]{2}{*}{ Items } & \multicolumn{3}{|c|}{ Convergent validity } & \multicolumn{2}{|c|}{$\begin{array}{c}\text { Internal Consistency } \\
\text { Reliability } \\
\end{array}$} & \multirow{2}{*}{$\begin{array}{c}\begin{array}{c}\text { Discriminant } \\
\text { Validity }\end{array} \\
\text { HTMT } \\
\text { confidence } \\
\text { interval does } \\
\text { not include 1 }\end{array}$} \\
\hline & & $\begin{array}{l}\text { Factor } \\
\text { loadings }\end{array}$ & $\begin{array}{l}\text { Indicator } \\
\text { reliability }\end{array}$ & AVE & $\begin{array}{l}\text { Cronbach's } \\
\text { alpha }\end{array}$ & $\begin{array}{l}\text { Composite } \\
\text { reliability } \\
\text { (CR) }\end{array}$ & \\
\hline \multirow{7}{*}{$\begin{array}{l}\text { Human } \\
\text { capital } \\
\text { factors }\end{array}$} & EQ3 & 0.811 & 0.657 & \multirow{7}{*}{0.512} & \multirow{7}{*}{0.837} & \multirow{7}{*}{0.878} & \multirow{7}{*}{ YES } \\
\hline & EQ4 & 0.658 & 0.432 & & & & \\
\hline & ET1 & 0.786 & 0.617 & & & & \\
\hline & ET3 & 0.815 & 0.664 & & & & \\
\hline & $\mathrm{S} 4$ & 0.535 & 0.286 & & & & \\
\hline & W1 & 0.769 & 0.591 & & & & \\
\hline & W3 & 0.578 & 0.334 & & & & \\
\hline \multirow{7}{*}{$\begin{array}{l}\text { Project } \\
\text { related } \\
\text { factors }\end{array}$} & FL2 & 0.765 & 0.585 & \multirow{7}{*}{0.572} & \multirow{7}{*}{0.872} & \multirow{7}{*}{0.902} & \multirow{7}{*}{ YES } \\
\hline & FL3 & 0.755 & 0.570 & & & & \\
\hline & LWC2 & 0.550 & 0.302 & & & & \\
\hline & LWC3 & 0.894 & 0.799 & & & & \\
\hline & PC1 & 0.666 & 0.443 & & & & \\
\hline & PC2 & 0.873 & 0.762 & & & & \\
\hline & PC5 & 0.739 & 0.546 & & & & \\
\hline \multirow{6}{*}{$\begin{array}{c}\text { Project } \\
\text { performance }\end{array}$} & PP1 & 0.704 & 0.495 & \multirow{6}{*}{0.625} & \multirow{6}{*}{0.887} & \multirow{6}{*}{0.909} & \multirow{6}{*}{ YES } \\
\hline & PP2 & 0.802 & 0.643 & & & & \\
\hline & PP3 & 0.822 & 0.675 & & & & \\
\hline & PP4 & 0.826 & 0.682 & & & & \\
\hline & PP5 & 0.789 & 0.622 & & & & \\
\hline & PP6 & 0.795 & 0.632 & & & & \\
\hline
\end{tabular}

This study also deals with the reflectiveformative type second-order construct to justify the relationship between the human capital factors, project-related factors, and skilled labour shortages. Thus, the inner Variance Inflation Factor (VIF) values were employed to examine collinearity issues between the constructs. According to Hair et al. (2014), high correlations are usually not expected between formative measurement models' constructs. Therefore, we have evaluated the constructs, including Human capital and project-related factors, as predictors of Skilled Labour
Shortages. The threshold value of VIF is less than 5 (Hair et al., 2017), and in this study, the VIF value of both Human capital factors and project-related factors were 2.304. Therefore, collinearity is not an issue between the formative constructs in this study.

In this study, "project performance" is the main construct. From the PLS path model estimation diagram (Fig. 2), the overall R2 is moderate. The threshold value of $0.25,0.5$ and 0.7 is often used to describe a weak, moderate, and strong determination coefficient (Hair et al., 2013). This study suggests that the three constructs, 


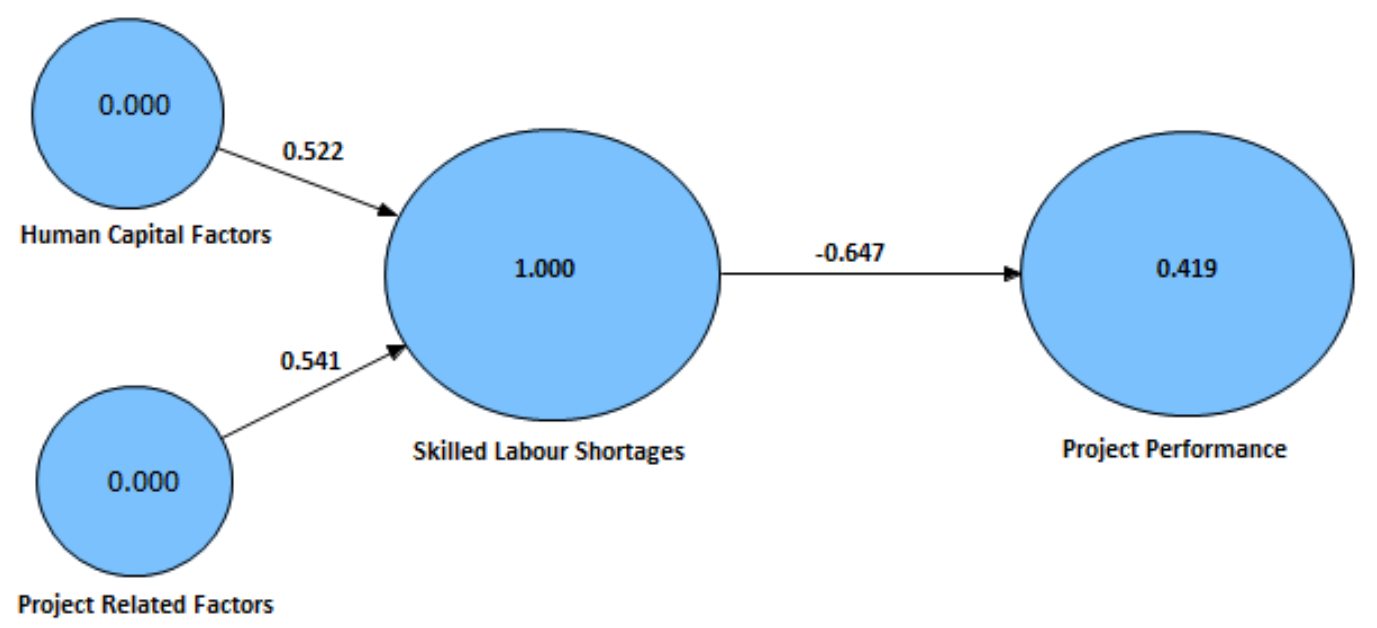

Fig. 2 - PLS path model estimation.

The relationship between constructs in PLSSEM can be determined by examining their path coefficients and related $\mathrm{t}$ statistics. Table 3 presents the results of the hypotheses testing. The negative path coefficient $\left(\mathrm{H}_{3}\right)$ indicates that as one variable increases, the other decreases and vice-versa (Stockburger, 2013). Since this study's hypothesis states that skilled labour shortages affect construction projects' performances; therefore, this study interprets the negative path coefficient as negative roles and thus lowers the project performance value.

Table 3: Significance testing results of the structural model path coefficients

\begin{tabular}{|c|l|c|c|c|}
\hline Hypothesis & \multicolumn{1}{|c|}{ Path } & $\begin{array}{c}\text { Path } \\
\text { coefficients }\end{array}$ & $\begin{array}{c}\mathrm{t} \\
\text { statistics }\end{array}$ & $\begin{array}{c}\text { Hypothesis } \\
\text { result }\end{array}$ \\
\hline $\mathrm{H}_{1}$ & $\begin{array}{l}\text { Human capital factors } \rightarrow \text { Skilled } \\
\text { labour shortages }\end{array}$ & 0.522 & 8.7593 & Accepted \\
\hline $\mathrm{H}_{2}$ & $\begin{array}{l}\text { Project-related factors } \rightarrow \text { Skilled } \\
\text { labour shortages }\end{array}$ & 0.541 & 8.9877 & Accepted \\
\hline $\mathrm{H}_{3}$ & $\begin{array}{l}\text { Skilled labour shortages } \rightarrow \\
\text { Project performance }\end{array}$ & -0.647 & 1.4800 & Accepted \\
\hline
\end{tabular}

This study supported and proved that human capital factors influence skilled labour shortages $(\mathrm{t}=8.7592, \mathrm{p}=0.00)$. The result indicated that human capital factors such as wages, skills, education, and training would influence the construction industry's skilled labour availability. This study also proved that project-related factors significantly influence skilled labour shortages $(\mathrm{t}=8.9877, \mathrm{p}=0.00)$. It indicates that working conditions, project complexity and foreign labours plays an essential role in influencing labours to engage in the construction sector. The analysis results have enabled us to conclude that the existence of skilled labour shortages affects project performance $(\mathrm{t}=1.4800, \mathrm{p}=0.00)$. The result proved that strong human resource management 
is critical as it affects improving construction project performance.

\subsection{CONCLUSION}

The finding of this study, in general, is to enrich and support existing literature in human resource management in the construction industry. This study gives some implications for practitioners and researchers studying skilled labour within the construction industry. The first implication is the ability of skilled labour shortages to affect the performance of construction projects. As shown in the results of our proposed framework, the skilled labour shortage has positively affected the performance of the construction project. This study supports the conclusion that skilled human resources are important factors in ensuring the success of construction projects (Hajela, 2012; Jarkas \& Younes, 2014). The second implication is the influence of human capital and project-related factors in influencing skilled labour shortages within the construction industry. Both factors have the same capabilities in causing skilled labour shortages in the construction industry. Therefore, both factors should be given considerable attention when planning skilled human resources in the construction industry.

\subsection{LIMITATIONS OF RESEARCH}

This study had several limitations, with the most noticeable limitations being the respondents' demographic profiles. Since only a small number of experienced respondents, the participants may not represent all the industrial sector workers. Additionally, all the participants were residing in Malaysia, which is still a developing country. Therefore, it may be noted that the results of similar studies conducted within developed countries and in industries outside the construction industry may vary from those of this study.

\subsection{SUGGESTIONS FOR FURTHER RESEARCH}

It is suggested that the interrelationships among variables proposed in this conceptual framework would provide a fruitful area for further study. The future empirical study is expected to be carried out in details to test this proposed framework and thus be able to develop a more comprehensive framework for the development of skilled labour in the construction industry.

\subsection{REFERENCES}

Alaloul, W.S., Musarat, M.A., Rabbani, M.B.A., Iqbal, Q., Maqsoom, A., \& Farooq, W. (2021). Construction sector contribution to economic stability: Malaysian GDP distribution. Sustainability, 13, 5012.

Amrizah, K., \& Nawal, K. (2013). The Relationship between Human Resource Management and Islamic Microfinance Providers' Performance: The Mediating Role of Human Capital. International Journal of Business and Social Science, 4(16), 52-57.

Ali, F., Amin, M., \& Cobanoglu, C. (2016). “An integrated model of service experience, emotions, satisfaction, and price acceptance: an empirical analysis in the Chinese hospitality industry", Journal of Hospitality Marketing \& Management, 25(4), 449-475.

Awan, M.A., \& Sarfraz, N. (2013). The impact of human capital on Company 
performance and the mediating effect of employee's satisfaction. IOSR Journal of Business and Management, 8(2), 76-82.

Aziz, N.M., \& Salleh, H. (2014). Case studies of the human critical success factors in information technology

implementation in Malaysian construction industry. Journal of Building Performance, 5(1).

Bagozzi, R. \& Yi, Y. (1988). On the evaluation of structural equation models. Journal of the Academy of Marketing Science, 16(1), 74-94.

Baloyi, L., \& Bekker, M. (2011). Causes of construction cost and time overruns: The 2010 FIFA World Cup stadia in South Africa. Acta Structilia, 18(1), 51-67.

Baqadir, A. A. (2013). A skills gap between industrial education output and manufacturing industry labour needs in the private sector in Saudi Arabia. University of Glasgow.

Baron, A. (2011). Measuring human capital. Strategic HR Review, 10(2), 30-35. doi:10.1108/14754391111108338

Beach, MJ (2009). A Critique of Human Capital Formation in the US and the Economic Returns to Sub-Baccalaureate Credentials. Educational Studies: A Journal of the American Educational Studies, 45(1), 24-38.

Becker, G.S. (1964), Human Capital: A Theoretical and Empirical Analysis with Special Reference to Education,
NBER, University of Chicago Press, Chicago, IL.

Becker, G.S. (1983). Human capital: A theoretical and empirical analysis with special reference to education. Chicago, IL: University of Chicago Press.

Bilau, A. A., Ajagbe, A. M., Kigbu, H., \& Sholanke, A. B. (2015). Review of shortage of skilled craftsmen in small and medium construction firms in Nigeria. Journal of Environment and Earth Science, 5(15).

Borjas, G.J. (2005), Labor

Economics, McGraw-Hill, New

York, NY.

Boswell, C., Stiller, S. \& Straubhaar, T. (2004). Forecasting labour and skills shortages: how can projections better inform labour migration polices?. Paper prepared for the DG Employment and Social Affairs of the European Commission, Hamburg Institute of International Economics, Hamburg.

Bosworth, D. (1993) Skill Shortages in Britain. Scottish Journal of Political Economy, $40,3,241-271$

Brown, A.W., Adams, J.D., \& Amjad, A.A. (2007). The relationship between human capital and time performance in project management: A path analysis. International Journal of Project Management, 25(1), 77-89.

Byrne, B.M. (2016). Structural equation modeling with AMOS: basic concepts, 
applications, and programming. Routledge.

Cepeda, D. M., Sohail, M., \& Ogunlowo, O. O. (2018). Understanding the critical success factors for delivery of megaprojects in Colombia. Paper presented at the Institution of Civil Engineers-Management, Procurement and Law, 171(2), 45-57.

Chin, W.K. (2012). The roles of human resource management in construction project success. Master's thesis, Universiti Tunku Abdul Rahman.

Coff, R.W. (2002). Human capital, shared expertise, and the likelihood of impasse on corporate acquisitions. Journal of Management, 28, 107-128.

Crook, T.R., Todd, S.Y., Combs, J.G., Woehr, D.J., \& Ketchen Jr, D.J. (2011). Does human capital matter? A meta-analysis of the relationship between human capital and firm performance. Journal of Applied Psychology, 96(3), 443456.

Faraji, Z. \& Abdolvand, N. (2016). Effects of human factor on the success of Information technology outsourcing. International Journal of Information Technology Convergence and Services. 6(1).

Farooqui, R. U., \& Saqib, M. (2010). Desirable Attributes and Skills for Graduating Construction Management Students. Paper presented at the Associated Schools of Construction Proceedings: 46th Annual International Conference.
Fernando, P., Fernando, N., \& Gunarathna, M. (2016). Skills developments of labourers to achieve the successful project delivery in the Sri Lankan construction industry. Civil and Environmental Research, 8(5), 86-97.

Fiori, C. (2003), "What's wrong with working in construction? How image and diversity issues are affecting the shortage of skilled labor", Proceedings of the Construction Research Congress, Honolulu, HI, 19-21 March, pp. 1-8.

Fitzsimons, P. (1999). Human capital theory and education. The Encyclopedia of Education. London: Macmillan.

Hair, J. F. J., Hult, G. T. M., Ringle, C. M., \& Sarstedt, M. (2017). A Primer on Partial Least Squares Structural Equation Modeling (PLS-SEM) (2nd ed.). Thosand Oaks, CA Sage Publications, Inc.

Hair, J.F., Celsi, M.W., Money, A., Samouel, P., \& Page, M. (2015). Essentials of Business Research Methods (3rd ed.). Armonk, NY: ME Sharpe.

Hair, J. F. J., Hult, G. T. M., Ringle, C., \& Sarstedt, M. (2014). A primer on partial least squares structural equation modeling (PLS-SEM). Sage Publications.

Hair, J.F., Hult, G.T.M., Ringle, C.M., \& Sarstedt, M. (2013). A Primer on Partial Least Squares Structural Equation Modeling (PLS-SEM). Thousand Oaks: Sage. 
Hajela, R. (2012). Shortage of skilled workers: A paradox of the Indian economy. SKOPE Research Paper, 111, 1-24.

Hamid, Singh, B. S. B. J., \& Mazlan, M. S. (2013). The construction labour shortage in Johor Bahru, Malaysia. International Journal of Research in Engineering and Technology, 2(10), 508-512.

Hashim, M. J., Osman, I., \& Alhabshi, S. M. (2015). Effect of intellectual capital on organisational performance. ProcediaSocial and Behavioral Sciences, 211, 207-214.

Haskel, J., \& Martin, C. (1993). Do skill shortages reduce productivity? Theory and evidence from the United Kingdom. The Economic Journal, 103(417), 386-394.

Healy, J., Mavromaras, K. \& Sloane, P. J. (2015). Adjusting to skill shortages in Australian SMEs. Applied Economics, 47(24), 2470-2487

Healy, J., Mavromaras, K. G., \& Sloane, P. J. (2011). Adjusting to skill shortages: Complexity and consequences. Retrieved from National Centre for Vocational Education Research (NCVER) by the National Institute of Labour Studies, Flinders University, Adelaide.

Henseler, J., Ringle, C. M., \& Sinkovics, R. R. (2009). The use of partial least squares path modeling in international marketing. In R. R. Sinkovics \& P. N. Ghauri (Eds.), Advances in International Marketing (Vol. 20, pp. 277-320). Bingley: Emerald.
Herath, T., \& Rao, H.R. (2009). Encouraging information security behaviors in organisations: Role of penalties, pressures and perceived effectiveness. Decision Support Systems, 47(2), 154-165.

Ho, P.H. (2016). Labour and skill shortages in Hong Kong's construction industry. Engineering, Construction and Architectural Management, 23(4), 533-550.

Hoffmann, A. \& Birnbrich, C., (2012), “The impact of fraud prevention on bank customer relationships: An empirical investigation in retail banking", International Journal of Bank Marketing, 30(5), $390-407$.

Hulland, J. (1999). Use of partial least squares (PLS) in strategic management research: A review of four recent studies. Strategic Management Journal, 20(2), 195-204.

Hwang, B.-G., Zhao, X., \& Tan, L.L.G. (2015). Green building projects: Schedule performance, influential factors and solutions. Engineering, Construction and Architectural Management, 22(3), 327-346.

Ibrahim, M. (2013). Contractors' perspective toward factors affecting labor productivity in building construction. Engineering, Construction and Architectural Management, 20(5), 446-460.

International Labour Organization (ILO) and Australian Aid. (2019). TRIANGLE in ASEAN Quarterly Briefing Notes. http://www.ilo.org/wcmsp5/groups/pu 
blic/---asia/---ro-

bangkok/documents/genericdocument

/wcms_614381.pdf

Ismail, R. \& Yuliyusman, F. (2014). Foreign labour on Malaysian growth. Journal of Economic Integration, 29(4), 657675.

Jaafar, M., \& Khalatbari, B. (2013). Knowledge and technical skills of project managers and time performance of power plant construction projects in Iran. Middle East Journal of Scientific Research, 16, 1141-1151.

Jarkas, A. M., \& Haupt, T. C. (2015). Major construction risk factors considered by general contractors in Qatar. Journal of Engineering, Design and Technology, 13(1), 165-194.

Jarkas, A.M. \& Younes, J.H. (2014). Principle factors contributing to construction delays in the State of Qatar. International Journal of Construction Project Management, 6(1), 39-62.

Jones, R. \& Goss, D. (1991). The Role of Training Strategy in Reducing Skill Shortages: Some Evidence from a Survey of Small Firms. Personel Review, Vol 20, pp 24-30.

Kabirifar, K., \& Mojtahedi, M. (2019). The impact of engineering, procurement and construction (EPC) phases on project performance: A case of largescale residential construction project. Buildings, 9(1), 15.

Karimi, H., Taylor, T. R., \& Goodrum, P. M. (2017). Analysis of the impact of craft labour availability on North American construction project productivity and schedule performance. Construction Management and Economics, 35(6), 368-380.

Karimi, H., Taylor, T. R., Goodrum, P. M., \& Srinivasan, C. (2016). Quantitative analysis of the impact of craft worker availability on construction project safety performance. Construction innovation, 16(3), 307-322.

Khan, R.A., Liew, M.S. \& Bin Ghazali, Z. (2014). Malaysian Construction Sector and Malaysia Vision 2020: Developed Nation Status. Procedia Soc. Behav. Sci., 109, pp 507-513.

Khan, B., Farooq, A., \& Hussain, Z. (2010). Human resource management: an Islamic perspective. Asia-Pacific Journal of Business Administration, 2(1), 17-34. doi: $10.1108 / 17574321011037558 \mathrm{Kw}$ ai, K. F. (2011). Economic Transformation Programme. Master Builders Journal, 3(4).

Kwon, D.B. (2009, October). Human capital and its measurement. In The 3rd OECD World Forum on "Statistics, Knowledge and Policy" Charting Progress, Building Visions, Improving Life (pp. 27-30).

Lill, I. (2008). Sustainable management of construction labour. Paper presented at the $25^{\text {th }}$ International Symposium on Automation and Robotic in Construction, June 26-29, Lithuania.

Lill, I. (2009). Multiskilling in construction - A strategy for stable employment. Technological and Economic 
Development of Economy, 15(4), 540560.

Lobo, Y. B., \& Wilkinson, S. (2008). New approaches to solving the skills shortages in the New Zealand construction industry. Engineering, Construction and Architectural Management, 15(1), 42-53.

Mahsud, R., Yukl, G., \& Prussia, G.E. (2011). Human capital, efficiency, and innovative adaptation as strategic determinants of firm performance. Journal of Leadership \& Organizational Studies, 18(2), 229246.

Marhani, M.A., Jaapar, A., \& Bari, N.A.A. (2012). Lean Construction: Towards enhancing sustainable construction in Malaysia. Procedia-social and behavioral sciences, 68, 87-98.

Marimuthu, M., Arokiasamy, L., \& Ismail, M. (2009). Human Capital Development and Its Impact on Firm Performance: Evidence from Developmental Economics. Journal of International Social Research, 2(8), 265-272.

Mavromaras, K., McGuinness, S., O’Leary, N., Sloane, P., \& Wei, Z. (2013). Job mismatches and labour market outcomes: panel evidence on university graduates. Economic Record, 89(286), 382-395.

Mavromaras, K., McGuinness, S., \& Fok, Y.K. (2009). Assessing the incidence and wage effects of overskilling in the Australian labour market. Economic Record, 85(268), 60-72.
Meng, X. (2012). The effect of relationship management on project performance in construction. International Journal of Project Management, 30(2), 188198.

doi:10.1016/j.ijproman.2011.04.002.

Mincer, J. (1974). Schooling, experience, and earnings. New York, NY: Columbia University Press.

Ministry of Human Resources (MOHR) Malaysia. (2019). Work and Labour Statistics. Series 19. No. 1/2019 March.

http://myhos.mohr.gov.my/ebook/istat istik1_2019/bil1_2019.pdf

Muathe, S. (2018). Human Capital Development and organisational performance: review \& critique of literature and A research agenda. International Journal of Innovation Education and Research, 6(2), 144-153.

Olsen, D., Tatum, M., \& Defnall, C. (2012). How industrial contractors are handling skilled labor shortages in the United States. Paper presented at the 48th Associated Schools of Construction (ASC) Annual International Conference Proceedings.

Oseghale, B., Abiola-Falemu, J., \& Oseghale, G. (2015). An Evaluation of Skilled Labour shortage in selected construction firms in Edo state, Nigeria. American Journal of Engineering Research, 4(1), 156-167.

Othman, A. (2014). A conceptual model for overcoming the challenges of mega construction projects in developing 
countries. African Journal of Engineering Research, 2(4), 73-84.

Papke-Shields, K.E., Beise, C., \& Quan, J. (2010). Do project managers practice what they preach, and does it matter to project success?. International journal of project management, 28(7), 650662.

Parvaiz, G. (2014). Skills expectationperformance gap: A study of Pakistan's accounting education (Doctoral dissertation).

Pelinescu, E. (2015). The impact of human capital on economic growth. Procedia Economics and Finance, 22, 184-190.

Perera, B.A.K.S., Rameezdeen, R., Chileshe, N., \& Hosseini, M.R. (2014). Enhancing the effectiveness of risk management practices in Sri Lankan road construction projects: A Delphi approach. International Journal of Construction Management, 14(1), 114.

Pheng, L.S., \& Chuan, QT (2006). Environmental factors and work performance of project managers in the construction industry. International journal of project management, 24(1), 24-37.

Praveen, R., Niththiyananthan, T., Kanarajan, S., \& Dissanayake, P. (2011). Understanding and mitigating the effects of shortage of skilled labour in the construction industry of Sri Lanka. Paper presented at the International Conference on Structural Engineering Construction and Management, Sri Lanka.
Rahim, F.A.M., Yusoff, N.S.M., Chen, W., Zainon, N., Yusoff, S., \& Deraman, R. (2016). The challenge of labour shortage for sustainable construction. Planning Malaysia Journal, 14(5).

Razak, A.R.A., Othman, A.A., \& Sundram, V.P.K. (2015). The relationships of human success factor, information technology, and procurement process coordination on operational performance in building construction industry-a proposed conceptual framework. Procedia economics and finance, 31, 354-360.

Salleh, N.M., Mamter, S., Lop, N.S., Kamar, I.F.M. \& Hamdan, N.A.M. (2014). The escalating of numbers of foreign workers in construction site. Paper presented at the Building Surveying, Facilities Management and Engineering Conference (BSFMEC2014), August 27, Perak, Malaysia.

Schultz, T.W. (1961). Investment in Human Capital. American Economic Review, 51, 1-17.

Sekaran, U., \& Bougie, R. (2010). Research Methods for Business A Skill-Building Approach (Fifth Edit.). John Wiley and Sons Ltd.

Shafie, H., Khuzzan, S. M. S., \& Mohyin, N. A. (2014). Soft skills competencies of quantity surveying graduates in Malaysia: Employers' views and expectations. International Journal of Built Environment and Sustainability, $1(1)$. 
Shah, C., \& Burke, G. (2005). Skills shortages: concepts, measurement and policy responses. Australian Bulletin of Labour, 31(1), 44.

Shehu, Z., \& Akintoye, A. (2008). Construction programme management skills and competencies: a deeper insight. The Built and Human Environment Review, 1, 1-17.

Stockburger, D.W. (2013). Introductory statistics: Concepts, models, and applications (3rd web ed.). Missouri: Missouri State University.

Sunindijo, R.Y., \& Zou, P.X. (2012). How project manager's skills may influence the development of safety climate in construction projects. International Journal of Project Organisation and Management, 4(3), 286-301.

Tehseen, S., Sajilan, S., Gadar, K., \& Ramayah, T. (2017). Assessing Cultural Orientation as a Reflective-Formative Second Order Construct-A Recent PLS-SEM Approach. Review of Integrative Business and Economics Research, 6(2), 38.

The Star Online. (2011, 25 June). Your 10 questions with Datuk Seri Michael Yam. The Star. Retrieved from https://www.thestar.com.my/business/ business-news/2011/06/25/your-10questions-with-datuk-seri-michaelyam

Theng, T.T., Nazihah, M.N. \& Jarud, R.K. (2020). Covid19: We must protect foreign workers. Khazanah Research Institute's Discussion Paper No.8/20. http://www.krinstitute.org/assets/cont
entMS/img/template/editor/20200607

_Discussion\%20Paper_Covid-

19_We\%20Must\%20Protect\%20Forei gn\%20Workers_Rev.pdf

Urbach, N., \& Ahlemann, F. (2010). Structural equation modeling in information systems research using partial least squares. Journal of Information Technology Theory and Application, 11(2), 5-40.

Veneri, CM. (1999). Can occupational labor shortages be identified using available data. Monthly Lab. Rev., 122, 15.

Wahab, A. (2020). Migrant workers and Covid19 outbreak in Malaysia. Institute of Malaysian and International Studies (IKMAS) Working Paper 3/2020. Universiti Kebangsaan Malaysia, Bangi.

Watson, M. (2007). Concerns for skills shortages in the 21 st century: a review into the construction industry, Australia. Australasian Journal of Construction Economics and Building, 7(1), 45-54

Weber, S. (2014). Human capital depreciation and education level. International Journal of Manpower, 35(5), 613-642.

Yaman, S. K., Abdullah, A. H., Mohammad, H., \& Hassan, F. (2015). Technical competency of construction manager in Malaysian construction industry. Applied Mechanics and Materials, 773, 1053-1059.

Yong, Y. C., \& Mustaffa, N. E. (2017). Critical success factors for Malaysian construction projects: An investigative 
review. International Journal of Built

Environment and Sustainability, 4(2).

Zakari, Z., Ali, N. M. A., Haron, A. T., Ponting, A. M., \& Hamid, Z. A. (2014) Exploring the barriers and driving factors in implementing building information modelling (BIM) in the Malaysian construction industry: A preliminary study. The Journal of The Institution of Engineers, Malaysia, 75(1).
Zaki, S. A., Mohamed, S., \& Yusof, Z. (2012). Construction skilled labour shortageThe challenges in Malaysian construction sector. OIDA International Journal of Sustainable Development, 4(5), 99-108. 